\title{
A new species of Isotomurus (Collembola: Isotomidae) without trichobothria
}

\author{
Новый вид рода Isotomurus (Collembola: Isotomidae) \\ без трихоботрий
}

\author{
Mikhail B. Potapov ${ }^{1} \&$ Anatoly B. Babenko ${ }^{2}$ \\ Михаиц Б. Потапов ${ }^{1}$, Анатолий Б. Бабенко ${ }^{2}$
}

\footnotetext{
${ }^{1}$ Moscow State Pedagogical University, Kibalchich str. 6, build. 5, Moscow 129164, Russia. E-mail: mpnk@orc.ru

${ }^{1}$ Московский педагогический государственный университет, ул. Кибальчича, д. 6, корп. 5, Москва 129164, Россия.

${ }^{2}$ Severtsov Institute of Ecology \& Evolution, Russian Academy of Sciences, Leninski pr. 33, Moscow 119071, Russia. E-mail: lsdc@mail.ru

${ }^{2}$ Институт проблем экологии и эволюции РАН им. А.Н. Северцова, Ленинский пр. 33, Москва 119071, Россия.
}

KEY WORDS: Collembola, Isotomidae, Isotomurus, new species, Russia.

КЛЮЧЕВЫЕ СЛОВА: Collembola, Isotomidae, Isotomurus, новый вид, Россия.

ABSTRACT. The paper provides a description of Isotomurus chaos sp.n., which, contrary to all known species of the genus excepting I. antennalis Bagnall, 1940, completely lacks trichobotria, the main differentiating character of the genus. Both these species possess a number of other common characters which are unique to the genus but clearly differ in coloration, mucronal seta and more complete setal cover on posterior side of dens in the new species.

РЕЗЮМЕ. В работе приведено описание Isotomurus chaos sp.n., который отличается от всех известных видов рода, кроме I. antennalis Bagnall, 1940, полным отсутствием трихоботрий — основного дифференцирующего признака рода. Кроме того, оба вида обладают ещё целым рядом общих признаков, уникальных для рода, но легко отличимы по окраске, наличию или отсутствию хеты на мукро и более полной хетотаксии денс у нового вида.

\section{Introduction}

Recent researches on the European Isotomurus Börner, 1903 [Deharveng \& Lek, 1993; Carapelli et al., 1995a-b, 2001; Fjellberg, 2007] have not only detected many new European species but also given new status to a number of forms previously regarded as color morphs of widespread Palaearctic species. All these detailed redescriptions of "old" species of Isotomurus permits us to compare European and eastern Palaearctic congeners characterized by similar color patterns. This comparison revealed that such forms are not always conspecific. Thus, a form which was registered as I. plumosus Bagnall, 1940 in several northern regions of the eastern Palaearctic, i.e. from Kanin and Taimyr peninsulas on the west [Babenko, 2003; Babenko \& Fjellberg, 2006] to Chukotka on the east [MacLean et al., 1978], has nothing to do with true I. plumosus as it was defined by Fjellberg, 2007 despite their identical colorations. This form is described below as a new species. The types are deposited in the collection of the Department of Zoology \& Ecology, Moscow State Pedagogical University (MSPU).

ABBREVIATIONS:

$A b d$. I-VI - abdominal segments;

accp-sensilla - tergal sensilla associated with $p$-row of setae;

Ant. 1-4 - antennal subsegments;

al-sensilla — anterolateral sensilla on tergites;

as-sensilla - anterosubmedial sensilla;

$i$ - inner sensilla of antennal organ;

lam. 1 - lamella 1 of maxillary head;

$m s$ - lateral microsensillum;

MSPU - Moscow State Pedagogical University;

$o$ - outer sensilla of antennal organ ;

PAO - postantennal organ;

p-row - posterior setal row on tergites.

\section{Isotomurus chaos Potapov et Babenko, sp.n.} Figs 1-17.

TYPE MATERIAL: Holotype, Russia (Arctic part), Western Taimyr, middle flow of Pyasina River, Ust'-Tareya $\left[73^{\circ} 15^{\prime} \mathrm{N} 90^{\circ}\right.$ $35^{\prime} \mathrm{E}$, sandy river bank with scarce vegetation, pitfall-traps, 1727.VII.2010, leg. A. Babenko (MSPU). Paratypes, 15 specimens on slides and 10 specimens in alcohol, ibidem (MSPU).

OTHER MATERIAL (all from Russia): NE European part, Nenets Autonomous Okrug, Dolgiy Island [ $\left.69^{\circ} 12^{\prime} \mathrm{N} 59^{\circ} 13^{\prime} \mathrm{E}\right]$, bog with Calta arctica, 21-28.VII.2004, leg. O. Makarova; N European part, Kanin Peninsula, Rybnaya River valley [ $\left.68^{\circ} 20^{\prime} \mathrm{N} 46^{\circ} 10^{\prime} \mathrm{E}\right]$, river bed, under stones, 29.VIII.1994, leg. A. Babenko; Western Siberia, Novosibirsk Region, $17 \mathrm{~km} \mathrm{~W}$ of Karasuk [53 $43^{\circ} \mathrm{N} 78^{\circ}$ 02'E], shore of Gusinoe Lake, 01.VII.1978; same region, shore of Krotovaya Lyaga Lake, 29.X.1978; same region and site, 19.X.1979; same region, Kusgan Lake, 30.IX.1983, all leg. S.K. Stebaeva; NW Tuva Republic, Kara-Khol' Lake, near water edge, 13.VII.2001, leg. S.K. Stebaeva; Middle Ural, Sverdlovsk Region, vicinities of Revda, Khomutovka, dell, floodplain with dropwort and alder, near the water edge, 29.VII.2002, leg. M. Potapov. 
We have also seen this species in two other locations of Western Taimyr (Ragozinka and Lake Ladannakh) and in material from Severnaya Zemlya Archipelago (a single specimen).

DESCRIPTION. $8+8$ ommatidia. PAO broad elliptical, as long as nearest ommatidium. Maxillary outer lobe with 4 sublobal hairs and bifurcate palp. Labrum with 4 prelabral setae and many setae on front, labral edge as common for the genus, with four sharp ridges and composite ventroapical ciliation. Labial palp with all usual papillae and complete set (16) of guards, 9-10 proximal, 8 basomedian and 5 basolateral setae present (Fig. 10). Ventral side of head with 3-4+3-4 postlabial setae. Maxillary head with all lamellae short, denticulate fields of lamellae without strong denticles. Lamella 1 slender, not expanded, without strong apical teeth and with numerous denticles along edge (Fig. 8). All antennal seg- ments apart from Ant. 2 with numerous thin sensilla as common for the genus. Ant. 1 additionally with several short and thick ("spine-like" sensilla), Ant. 3 with several thick and many thin sensilla, some sensilla very long and curved at tip, inner sensilla of antennal organ considerably larger then outer sensilla and other thick sensilla of the segment (Fig. 9). Ant. 4 with bifurcate subapical pin-seta.

Body with more or less uniform cover of stiff setae unequal in length and lack clear ciliation (Fig. 2). Neither trichobothria nor true macrosetae differentiated. Some setae, especially those of $p$-row rather long, ratio longest setae to length of $A b d$. V as $0.28-0.35$. Number of macrosensilla in full grown specimens as 4(3),4/3,4-5(3),5-6(7), >12,>9 (Fig. 1 ), in first instar juveniles as 4,4/3,4,4-5,12-17,7-9 (only two juveniles were checked). Th. II-III and $A b d$. I with 3

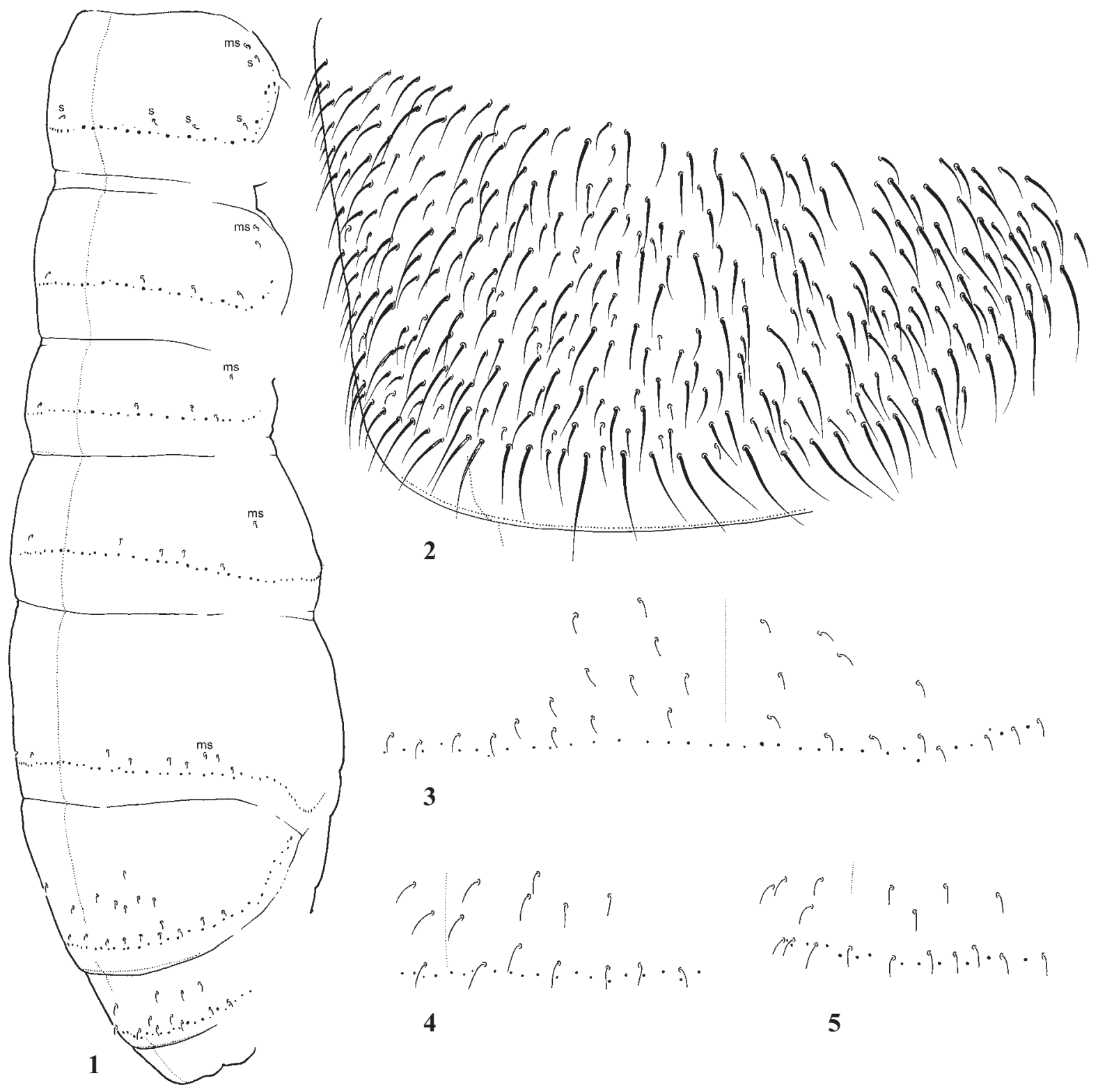

Figs 1-5. Isotomurus chaos sp.n., chaetotaxy: 1 - arrangement of sensilla and microsensilla on body; 2 - chaetotaxy of $A b d$. IV; $3-$ 5 - variants of sensillar patterns of $A b d$. IV (3) and $A b d$. V (4, 5); $s$ - (macro)sensillum; $m s-$ microsensillum.

Рис. 1-5. Isotomurus chaos sp.n., хетотаксия: 1 - расположение сенсилл и микросенсилл на теле; 2 - хетотаксия Abd. IV; $3-$ 5 - варианты расположения сенсилл на $A b d$. IV (3) и $A b d . \mathrm{V}(4,5) ; s-$ (макро)сенсилла; $m s$ - микросенсилла. 

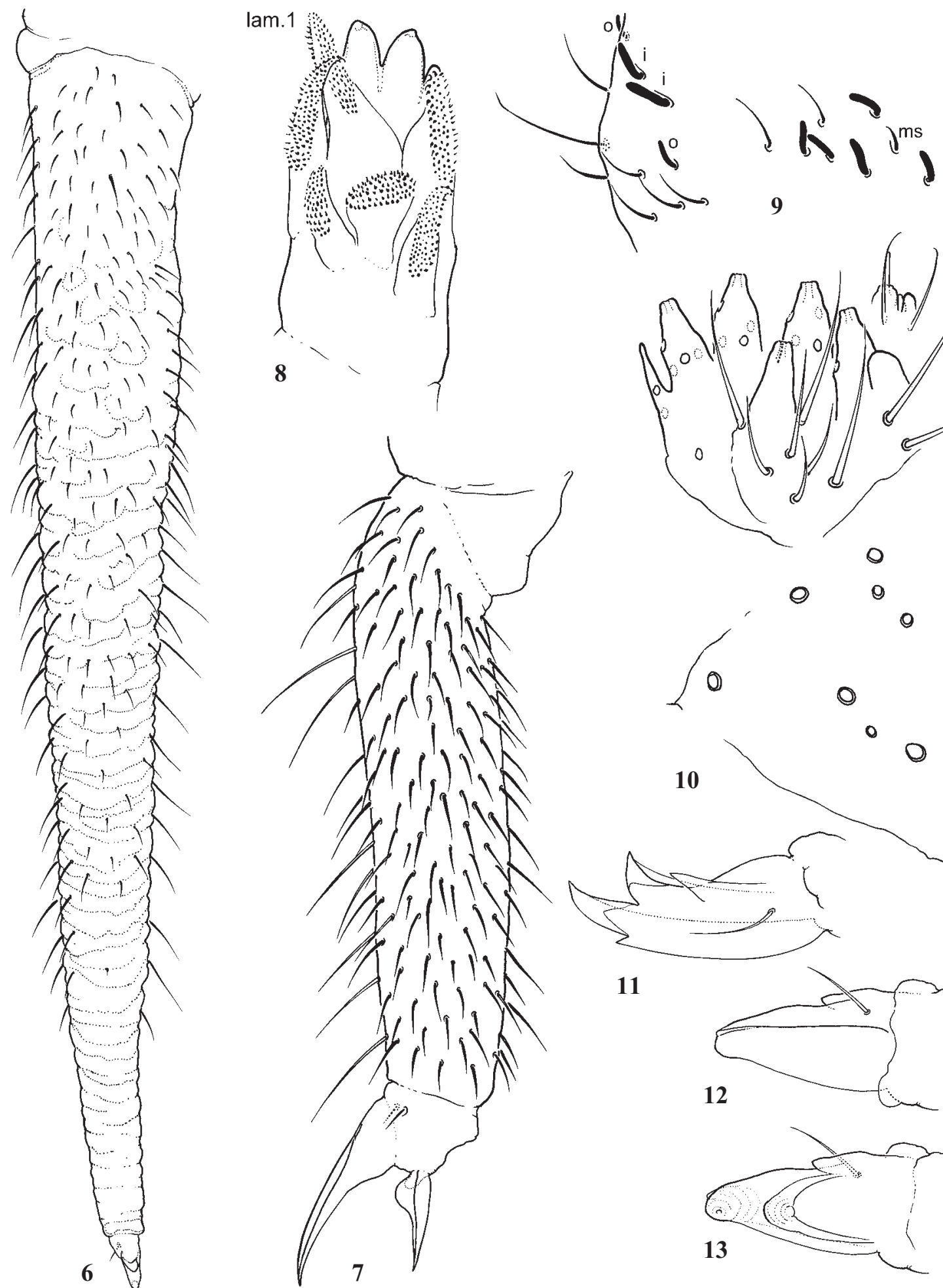

9

Figs 6-13. Isotomurus chaos sp.n.: 6- dens, posterior view; 7 - tibiotarsus of Leg 3;8 - maxillary head, inner view; 9 - sensilla of distal part of Ant. 3;10 - labium (proximal and hypostomal setae shown, guards, apical setae of papillae, and basomedian setae shown by sockets); 11-13 - mucro, lateral (11), anterior (12), posterior (13) views; $i$ - inner sensilla of antennal organ; $o-$ outer sensilla of antennal organ; lam.1 - lamella 1 of maxillary head; $m s$ - lateral microsensillum.

Рис. 6-13. Isotomurus chaos sp.n.: 6 - денс, вид сзади; 7 - тибиотарзус третьей пары ног; 8 - головка максиллы, вид с внутренней стороны; 9 - сенсиллы дистальной части Ant. $3 ; 10$ - лабиум (показаны проксимальные и гипостомальные хеты, а также основания “защитных”, базомедиальных и апикальных хет папилл); 11-13 - мукро, вид сбоку (11), спереди (12) и сзади (13); $i$ - внутренняя сенсилла антеннального органа; $o$ - наружная сенсилла антеннального органа; lam. 1 - ламелла 1 головки максиллы; $m s$ - латеральная микросенсилла. 
$a c c p$-sensilla just in front of $p$-row, also a pair of lateral alsensilla present on each side of thoracic tergites. Number of sensilla on abdominal tergites continuously increases towards the tip, $a c c p$-sensilla situated in front of, rarely within $p$-row. On $A b d$. IV and V considerable part of medial area covered with as-sensilla. Asymmetry of number and arrangement of sensilla appears to be a rule on these segments (Figs 3-5). Microsensilla 1,1/1,1,1 in number, set in anterior part of tergite on $A b d$. I and usually on $A b d$. II (rarely close to level of $a c c p$-sensilla), on $A b d$. III slightly in front of $a c c p$-row, very rarely in middle position.

Legs with rather thin claws, ratio tibiotarsus : inner edge of claw as 1.9-2.7 on Leg 1 and 3.7-4.7 on Leg 3. Claw with small lateral tooth and minute outer one (hardly visible in some specimens), distinct inner tooth absent (Fig. 7). Empodium without inner tooth, 1.6-1.8 times shorter than inner edge of claw. Tibiotarsi in adult and large specimens with 10 or more setae in distal whorl due to tibiotarsal polychaetosis, in smaller individuals only $8(9)$ distal setae present. Retinaculum with $4+4$ teeth and 9-13 setae. Ventral tube with 3+3 laterodistal, 4-7+4-7 anterior and 17-24 posterior setae. Manubrium densely covered by setae, with more than 120 ones on anterior side. Manubrial thickening as common for the genus, with several pointed teeth in medial part. Dens rather thick, continuously narrowed, with numerous short setae on posterior side which cover from $2 /$ 3 to $3 / 4$ of its length. One of posterior setae in basal part slightly longer than others. Posterior side of dens crenulated, wrinkles regular in distal half and more disordered in basal half (Fig. 6). Mucro with four teeth as common for the genus and invariable seta on outer side. "Apical" tooth small and positioned away from the top, subapical tooth with strong lamella running along outer edge to mucro base, middle tooth scoop-like, with two lamellae running back, outer proximal tooth of common shape. Ventral edge of mucro usually armed with ridge, varies depending on indi-

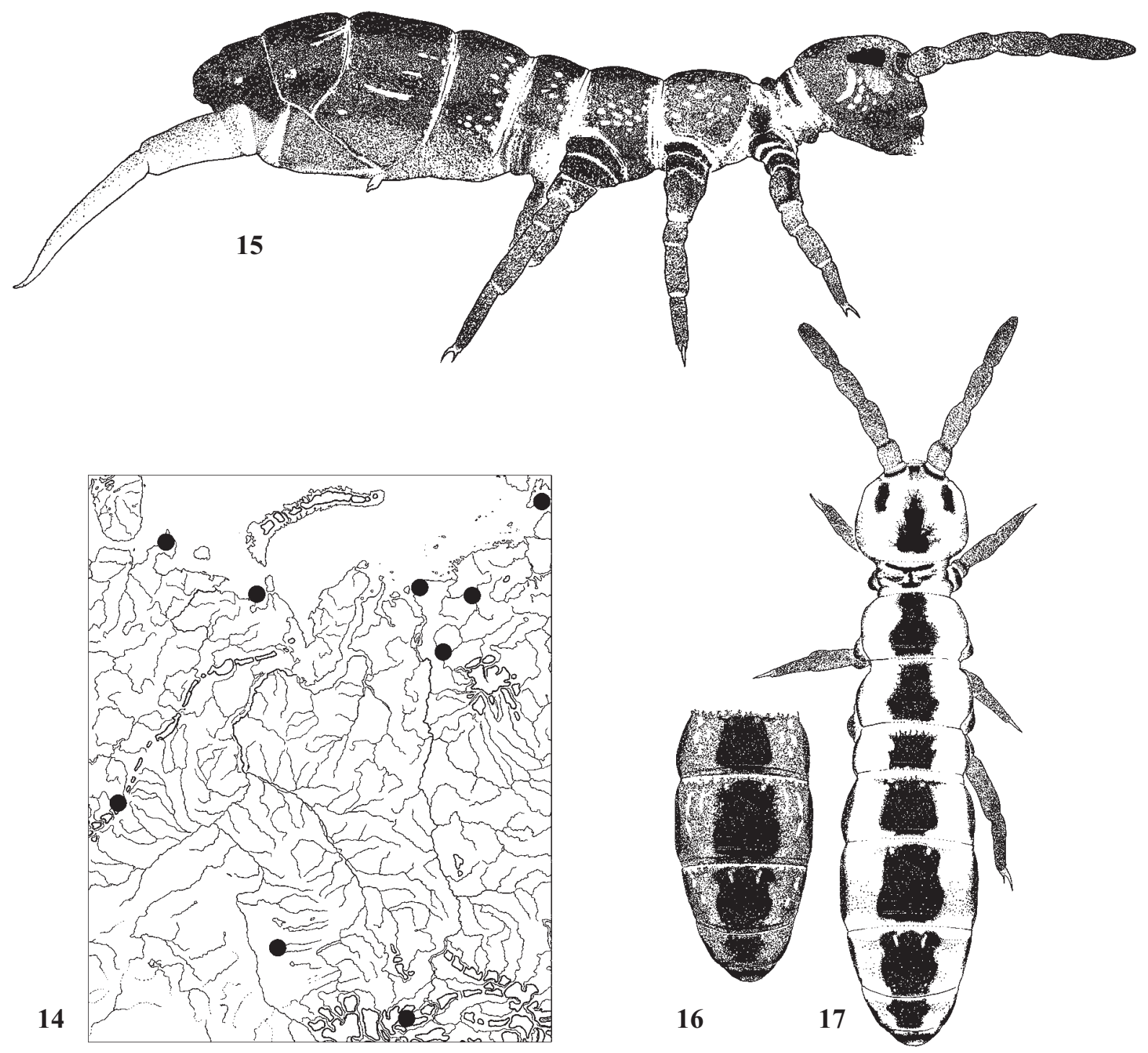

Figs 14-17. Isotomurus chaos sp.n.: 14 - records in Russia; 15-17 - variants of coloration, large dark-colored individual (15), examples of normal color pattern (16-17), darker (16), and lighter (17).

Рис. 14-17. Isotomurus chaos sp.n.: 14 - места находок в России; 15-17 - варианты окраски, крупный темно-окрашенный экземпляр (15), нормальная окраска (16-17), более тёмная (16) и светлая (17). 
vidual (Figs 11-13). Ratio mucro : claw III as 0.6-0.8. First instar juveniles without ventroapical manubrial setae and seta on mucro.

Body size 2-3 mm. Background pale yellowish, with sharp broad mid-dorsal band running from $T h$. II to $A b d$. VI. interrupted in intersegmental areas (Figs 16-17). Lateral parts of segments and basal areas of legs dark. In some individuals, background darker and therefore partly masks the main color pattern. Large individuals can be wholly dark, brownish black (Fig. 15). Young individuals paler, middorsal band always present. Posterior part of head with large black medial spot, eye area black, areas at bases of antennae darkened. Antennae and foots diffusely dark, furca paler. Reproductive males without modified setae laterally on $\mathrm{Abd}$. III-IV.

DISCUSSION. Despite the absence of trichobotria (main diagnostic character of the genus), the general impression of the new species (head shape and position, increased number of labial setae, only $3+3$ laterodistal setae on ventral tube, shape of furca, etc. ) supports its position within Isotomurus. No doubt that among known species it resembles only I. antennalis Bagnall, 1940, the peculiar member of the genus, distributed in northern Europe. Initially, the latter was described as a unique species of the genus without any indication of the presence of trichobothria [Bagnall, 1940]. The analysis of other morphological peculiarities of I. antennalis led to its exclusion from [Murphy, 1958] or keeping [Fjellberg, 2007] within Isotomurus. Now the latter opinion is more common. Both these species share the complete absence of trichobothria and macrosetae on abdominal tip and on tibiotarsi 3 , virtually identical maxillary head differing from that in other congeners, and the presence of several thick sensilla on Ant. 3. Fjellberg [2007] also mentioned the increased number of sensilla on $\mathrm{Abd}$. IV in I. antennalis which is typical of $I$. chaos sp.n. as well. The new species differs from I. antennalis in having a seta on mucro (always absent in the latter), distinct "3-lined" color pattern (very similar to that of I.plumosus, but unlike a transverse banding typical of I. antennalis), and more complete setal covering of posterior side of dens (in I. antennalis only proximal half of dens is covered with setae). The presence of only 3 accpsensilla on thoracic tergites in I. chaos sp.n. can probably be used as an additional diagnostic feature of the new species as all so far studied congeners possess 5 such sensilla [Carapelli et al., 2001]. Unfortunately the character is still unknown for I. antennalis.

Due to a combination of unique characters, I. antennalis and $I$. chaos sp.n. can not be placed to any known speciesgroup of the genus [Deharveng \& Lek, 1993; Potapov, 2001]. They can formally be drawn together with representatives of the 'gallicus' group characterised by the absence of trichobortia at least on some abdominal tergites (formula 0,0 $1,1)$ or with the 'alticolus' group due to increased number of sensilla on abdominal tip. All other peculiarities of these groups are, however, different and we suppose a convergent nature of these similarities.
NAME DERIVATION. The name reflects irregular, rather chaotic arrangements of sensilla on last abdominal segments which is characteristic of the new species (from Greek $\chi \alpha ́ o s-c h a o s)$.

DISTRIBUTION AND ECOLOGY.I.chaos sp.n. seems to be a widespread polyzonal species in the western part of Siberia but in the European part of Russia it is probably restricted to its northernmost areas (Fig. 14). After our observations the new species is not very common in sampling sites, and prefers banks of rivers and lakes like the most other members of the genus.

ACKNOWLEDGEMENTS. We would like to express our sincere thanks to O.L. Makarova and S.K. Stebaeva for the loan of valuable material and for their friendly and fruitful comments. The paper has been supported through grants of the Russian Foundation for Basic Research (projects 11-0400941, 11-04-01725) and through several scientific programmes of the Russian Academy of Sciences.

\section{References}

Bagnall R.S. 1940. Notes on British Collembola // Entomol. Mon. Mag. Vol.76. P.97-102.

Babenko A.B. 2003. [Landscape chorology of Collembola on Taimyr Peninsula. II. Latitudinal differentiation of the fauna] // Zool. Zhurn. Vol.82. No.9. P.1051-1063 [in Russian, English translation: Entomol. Rev. Vol.83. No.9. P.1194-1207].

Babenko A., Fjellberg A. 2006. Collembola Septentrionale. A Catalogue of Springtails of the Arctic Region. Moscow: KMK Scientific Press Ltd. 190 pp.

Deharveng L., Lek S. 1993. Remarques sur la morphologie et la taxonomie du genre Isotomurus Börner, 1903 et description de deux espèces nouvelles de France (Collembola: Isotomidae) // Ann. Soc. Entomol. Fr. N.S. T.29. Fasc.3. P.245-259.

Carapelli A., Fanciulli P.P., Frati F., Dallai R. 1995a. The use of genetic markers for the diagnosis of sibling species in the genus Isotomurus (Insecta, Collembola) // Boll. Zool. Vol.62. P.71-76.

Carapelli A., Frati F., Fanciulli P.P., Dallai R. 1995b. Genetic differentiation of six sympatric species of Isotomurus (Colembola, Isotomidae); is there any difference in their microhabitat preference? // Eur. J. Soil Biol. Vol.31. No.2. P.87-99.

Carapelli A., Frati F., Fanciulli P.P. \& Dallai R. 2001. Taxonomic revision of 14 south-western European species of Isotomurus (Collembola, Isotomidae), with description of four new species and the designation of the neotype for I. palustris // Zool. Scr. Vol.30. No.2. P.115-143.

Fjellberg A. 2007. The Collembola of Fennoscandia and Denmark. Part. II: Entomobryomorpha and Symphypleona // Fauna Entomol. Scand. Vol.42. 264 pp.

MacLean S.F., Behan V., Fjellberg A. 1978. Soil Acari and Collembola from Chaun Bay, Northern Chukotka // Arct. Alp. Res. Vol.10. P.559-568.

Murphy D.H. 1958. Notes on Isotomurus with a redescription of Isotoma antennalis (Bagnall) (Collembola, Isotomidae) // An. Mag. Nat. Hist. Ser.13 Vol.50. P.677-681.

Potapov M. 2001. Synopses on Palaearctic Collembola. Volume 3. Isotomidae // Abh. Ber. Naturkundemus. Görlitz Bd.73. Hf.2. S.1-603. 